\title{
Interspecific Competition Interacts With the Spatial Distribution of a Palatable Grass to Reduce Its Recruitment
}

\author{
Pablo A. Cipriotti ${ }^{1}$ and Martín R. Aguiar ${ }^{2}$ \\ Authors are ${ }^{1} \mathrm{PhD}$ candidate and ${ }^{2}$ Adjunct Professor and Independent Investigator, Cátedra de Ecologia-IFEVA, \\ Departamento de Recursos Naturales y Ambiente, Facultad de Agronomia, Universidad de Buenos Aires/CONICET. \\ Avda San Martin 4453, C1417DNS, Buenos Aires, Rep. Argentina
}

\begin{abstract}
Most arid and semiarid ecosystems around the world have been grazed by domestic herbivores. In many cases, grazing has degraded vegetation and soil. The possibility of restoring rangeland's good condition depends, partially, on the ability of remaining populations of desirable species to recover. In this work, we studied the exact spatial distribution of remaining palatable adult plants in fields with different grazing history (i.e., seed sources) and quantified the effect of interspecific competition with less palatable grasses on seedling emergence and survival (i.e., regeneration constraints). We worked in a Patagonian steppe composed of shrubs and perennial tussock grasses that has been grazed by sheep for $>100$ years. In order to evaluate the location of seed sources, we mapped the location of a palatable species (Bromus pictus Hook.) in paddocks with different long-term grazing intensity. In addition, we sowed seeds of B. pictus close to 2 dominant, less palatable grasses in 2 different years to evaluate the role of interspecific interactions on regeneration and the effects of climate variability. The proportion of $B$. pictus plants growing in protected places near less palatable species significantly increased with grazing intensity. Competition effects on emergence, survival, and growth depended on the year's moisture regime. During the dry year, competition with less palatable grasses reduced the emergence, survival, height, and number of leaves of palatable grass seedlings by $30 \%, 55 \%, 48 \%$, and $40 \%$, respectively. In the wet year, there were no effects of competition on emergence and height, and the effects on survival depended on the species of the less palatable neighbors. Our study supports the idea that management for recovering degraded rangelands in this ecosystem may benefit from considering the spatial distribution of remaining plants. It also indicates that the susceptibility of demographic processes to interspecific competition depends on the year and neighbor species.
\end{abstract}

\section{Resumen}

La mayoría de los ecosistemas áridos y semiáridos del mundo han sido apacentados por herbívoros domésticos. En muchos casos, el apacentamiento ha deteriorado la vegetación y el suelo. La posibilidad de restaurar la buena condición de estos pastizales depende parcialmente de la habilidad de las poblaciones remanentes de especies deseables para recuperarse. En este trabajo, estudiamos la distribución espacial exacta de las poblaciones remanentes de plantas adultas de un pasto palatable en pastizales con diferente historial de apacentamiento (fuentes de semillas) y cuantificamos el efecto de la competencia interespecífica con pastos menos palatables sobre la emergencia y supervivencia de plántulas (restricciones a la regeneración). Trabajamos en una estepa semiárida Patagónica co-dominada por arbustos y pastos perennes, que había sido apacentada por ovinos durante más de 100 años. Para evaluar la localización de las fuentes de semilla mapeamos la ubicación de una especie palatable (Bromus pictus Hook.) en potreros con diferente intensidad de apacentamiento. Además, en dos años diferentes, hicimos siembras de esta misma especie cerca de dos especies de pastos menos palatables dominantes para evaluar el papel de las interacciones interespecíficas sobre la regeneración y el papel de la variación climática. La proporción de plantas de B. pictus creciendo en lugares protegidos cerca de las especies menos palatables se incrementó significativamente con la intensidad de apacentamiento. Los efectos de la competencia en la emergencia, supervivencia y crecimiento de plántulas dependieron del régimen de humedad del año. Durante el año seco, la competencia con pastos menos palatables redujo la emergencia, supervivencia, altura y número de hojas de plántulas del pasto palatable en un 30\%, 55\%, 48\% y 40\% respectivamente. Mientras que durante el año húmedo no hubo efectos de la competencia sobre la emergencia y la altura, y los efectos sobre la supervivencia dependieron de la especie de pasto menos palatable involucrada en el proceso de competencia. Nuestro estudio soporta la idea de que el manejo para recuperar los pastizales degradados en este ecosistema puede mejorar ser más benéfico si se considera la distribución espacial de las plantas remanentes. Además, señala que la susceptibilidad de los procesos demográficos a la competencia interespecífica dependen del año y de la especie menos palatable contigua.

Key Words: associations, Bromus pictus, climatic variation, Patagonian steppes, rangelands, recovery, refuges, spatial patterns

Research was funded in part by grants from University of Buenos Aires (UBACyT AG 19 and G001) and the Agencia Nacional para la Promoción Científica y Tecnológica (APCyT, PICT 99 01-06641). P.A.C. was supported by a doctoral fellowship from CONICET and M.R.A. is member of CONICET.

Correspondence: Pablo A. Cipriotti, Cátedra de Ecología-IFEVA, Departamento de Recursos Naturales y Ambiente, Facultad de Agronomía, Universidad de Buenos Aires/CONICET. Avda San Martin 4453, C1417DNS, Buenos Aires, Rep. Argentina. Email: cipriott@agro.uba.ar; Webpage: http://www.agro.uba.ar/users/cipriott/myweb/

Manuscript received 14 August 2003; manuscript accepted 23 March 2005. 


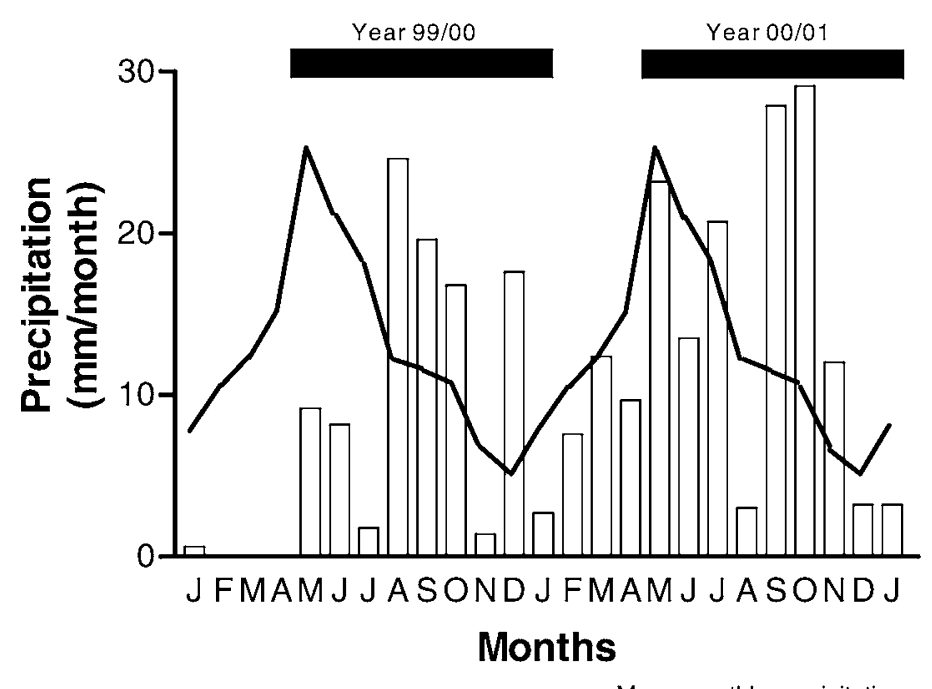

- Mean monthly precipitation

Current monthly precipitation

Figure 1. Monthly precipitation during the 2 years from January 1999 to January 2001 (white empty bars) and mean monthly precipitation (black solid line) ( $n=25$ years). The accumulated precipitation during the first and second years was 101.9 and $135.8 \mathrm{~mm}$, respectively.

\section{INTRODUCTION}

Most arid and semiarid rangelands around the world have been grazed by domestic herbivores (Milchunas and Lauenroth 1989; Belsky 1992; McNaughton 1993; Oesterheld et al. 1999). In many rangelands, inadequate grazing management triggered degradation evidenced by decreases in plant cover, changes in plant-community structure, decreases in the abundance of palatable species, encroachment of woody plants, and soil erosion (Westoby 1980; Walker et al. 1981; Brown and Archer 1989; Archer 1990; Schlesinger et al. 1990; van Auken 2000). Furthermore, grazing can disrupt the original spatial patterns of plant communities at different scales and generate new associations among remnant species (Bakker et al. 1983; Papatheodorou et al. 1993; Berg et al. 1997; Dale and Zbigniewicz 1997; Adler et al. 2001; Cipriotti and Aguiar 2005). In many rangelands throughout the world, the remaining individuals of the highly preferred species (i.e., palatable species) grow in places protected from herbivores, e.g., refuges under the canopy of woody plants, cactus clumps, or near less palatable species (Bakker et al. 1983; Berg et al. 1997; Rebollo et al. 2002; Oesterheld and Oyarzábal 2004). This close association among adult plants results from a balance between protection against domestic grazers and interspecific competition (Oesterheld and Oyarzábal 2004).

Low-input management for restoring degraded rangelands depends on promoting both the seeding of remaining palatable plants and the emergence and establishment of new plants. Closeness to a less palatable species promotes the seeding (Oesterheld and Oyarzábal 2004), but on the other hand, seedling survival can be strongly constrained by competition (Aguilera and Lauenroth 1993). In communities with sparse vegetation, seeds tend to accumulate close to established vegetation (see references in Aguiar and Sala 1997). As a consequence, seedling-adult interactions must be highly frequent. Although the trade-off of adult-adult contact has been studied in different grazing systems (Bakker et al. 1983; Berg et al. 1997; Rebollo et al. 2002; Oesterheld and Oyarzábal 2004), there still is a lack of knowledge about the seedling-adult contact and the effect of interannual variability in climate. In our view, less palatable adults protect palatable adults against grazing, but seedling survival close to less palatable adults might be low because of asymmetric competition. In this sense, changes in the local spatial distribution patterns promoted by grazing could enhance the role of interspecific interactions (Crawley 1990; Owens and Norton 1992; Defosse et al. 1997; Moretto and Distel 1997; Fowler 2002).

The main objectives of this work were to study the spatial distribution of adult individuals of a palatable species (i.e., seed sources) in pastures with different grazing intensity and to characterize the effects of less palatable adult grasses on the regeneration of palatable grass species (emergence, growth, and survival of seedlings). We worked in a Patagonian steppe codominated by grasses and dwarf shrubs. The main agricultural activity during more than 100 years has been the extensive raising of sheep for wool production (Soriano et al. 1983). In many fields of these steppes, populations of palatable tussock grass species were reduced as a consequence of overgrazing. Instead, less palatable species maintained or increased their original abundance (Perelman et al. 1997). In this study, we focused on a palatable species, Bromus pictus Hook, which is highly preferred by sheep (Bonvisutto et al. 1983; Somlo et al. 1997). We were interested in answering 3 questions related to the possibility of recovering overgrazed steppes. 1) Does grazing intensity affect the spatial distribution of adult plants (seed sources) of a palatable species? 2) Does competition from less palatable adult grasses constrain the regeneration of a palatable grass? 3) Does interannual variability in climate affect the intensity and importance of interspecific competition?

\section{MATERIALS AND METHODS}

\section{Study Site}

We worked at the INTA Experimental Field Station in Río Mayo, Chubut, Argentina (lat $45^{\circ} 41^{\prime} \mathrm{S}$; long $70^{\circ} 16^{\prime} \mathrm{W}$ ), located at $500 \mathrm{~m}$ above sea level. Mean annual precipitation is $152 \pm 44 \mathrm{~mm}$, and more than $80 \%$ of the precipitation falls during autumn and winter (Jobbágy et al. 1995). Mean annual temperature is $8.1^{\circ} \mathrm{C}$; mean monthly temperature ranges from $2^{\circ} \mathrm{C}$ in July to $14^{\circ} \mathrm{C}$ in January. We recorded the precipitation fallen during the field experiments, from January 1999 to January 2001, at the study site (Fig. 1). During the first year, accumulated rainfall was lower than the average $(101.9 \mathrm{~mm}$ vs. $118.5 \mathrm{~mm}$ ). Instead, during the second year (January 2000), the accumulated rainfall was greater than the site average $(135.8$ $\mathrm{mm}$ vs. $118.5 \mathrm{~mm}$ ) and was concentrated toward the end of spring. The soil is sandy and includes pebbles throughout the profile. There is a cemented calcareous layer at approximately $0.6 \mathrm{~m}$ (Paruelo et al. 1988). The vegetation of the area corresponds to the dominant community of the Occidental District of the Patagonian steppe (Soriano 1956; Golluscio et al. 1982; León et al. 1998). This community is codominated by grasses and dwarf shrubs, which cover $25 \%$ and $12 \%$, respectively (Fernández et al. 1991). The dominant perennial grass 
species are Stipa speciosa Trin. Et Rupr., Poa ligularis Nees ap. Steud., Stipa humilis Vahl, and B. pictus Hook. The dominant shrubs species are Senecio filaginoides AD., Mulinum spinosum (Cav.) Pers. and Adesmia campestris (Rendle) Skottsb. Shrubs and tussock grasses contribute more than $96 \%$ of the total plant cover and plant biomass (Golluscio et al. 1982; Fernández et al. 1991; Jobbágy and Sala 2000). Many species are forbs that contribute $<1 \%$ to plant cover (Golluscio and Sala 1993).

\section{Mapping Vegetation and the Spatial Distribution of a Palatable Grass (B. pictus)}

We mapped vegetation in fields with different history of grazing intensity: ungrazed, grazed, and overgrazed. Each grazing condition had 3 replicates located in different paddocks (9 maps in total). Ungrazed and grazed paddocks were located in the Experimental Field Station, whereas overgrazed paddocks were located on privately owned farms. Ungrazed paddocks were grazing exclosures (46, 28, and 17 years old). Grazed and overgrazed paddocks ( $>200$ ha in area) had moderate stocking rates $(\sim 0.2$ sheep/ha), and high stocking rates $(\sim 0.4$ sheep/ha), respectively. The mapped sites were randomly distributed in a $100-\mathrm{km}^{2}$ area, and we excluded sites that were close to water points or fences.

We mapped vegetation in $10 \mathrm{~m} \times 10 \mathrm{~m}$ plots located in the 9 paddocks ( 3 plots in each grazing condition). We divided the plot into cells of $0.25 \mathrm{~m} \times 0.25 \mathrm{~m}$. Then we mapped the contour of every individual plant of shrub and grass in the plots through hand drawing on a piece of paper with a grid similar to the one established on the ground. We employed 3 categories: palatable grass (B. pictus), less palatable grasses, and shrubs. Palatable grass $B$. pictus was selected according to the dietary studies made in the region and the important attributes related to forage quality, quick regeneration, and local extinction risk in overgrazed fields (Bonvisutto et al. 1983; Somlo et al. 1997; Aguiar et al. 1999; Rotundo and Aguiar 2004). On the other hand, less palatable grasses were mostly Stipa spp., the dominant tussock grass species in grazed fields. We defined associated individuals of palatable grass $B$. pictus as individuals growing under the shrub's canopy (minor cases) or in contact with less palatable grasses (Stipa spp.). We built a contingency table with the different counts of associated individuals across the 3 grazing conditions and then performed a goodness-of-fit test (chi-square) to test differences between treatments (Steel and Torrie 1988).

\section{Competition Experiment Between Palatable Seedlings and Less Palatable Adult Grasses}

We studied competition with a 3-way factorial experiment with split-plot design. The first factor was neighbor (Stipa speciosa or Stipa humilis), the second factor was competition (full competition or reduced competition), and the third factor was year (1999-2000 or 2000-2001). In May 1999 (cold season), we selected adult tussocks of $S$. speciosa $(n=20)$ and S. humilis $(n=20)$. Selected plants had similar aboveground biomass and low accumulation of dead material. We reduced competition in the neighborhood of 10 randomly selected plants per species. To reduce belowground competition, we dug a pit $(20 \mathrm{~cm}$ in diameter and $30 \mathrm{~cm}$ in depth) close to Stipa spp. plants and
Table 1. Summary of goodness-of-fit test of association between individuals of a palatable grass species (Bromus pictus) and less palatable species across the three grazing conditions (ungrazed, grazed, and overgrazed). Each grazing condition results from sum of three $100-\mathrm{m}^{2}$ plots. Bold letters indicate the partial chi-square with the most contribution to the global chi-square and $P$-value $<5 \%$.

\begin{tabular}{|c|c|c|c|c|c|}
\hline \multirow{3}{*}{$\begin{array}{l}\text { Grazing } \\
\text { conditions }\end{array}$} & \multicolumn{2}{|c|}{$\begin{array}{l}\text { Location of } \\
\text { Bromus pictus }\end{array}$} & \multirow[b]{3}{*}{ Total } & \multirow{2}{*}{\multicolumn{2}{|c|}{$\begin{array}{c}\text { Associated plants of } \\
\text { Bromus pictus (percentage) }\end{array}$}} \\
\hline & \multirow[b]{2}{*}{ Associated } & \multirow{2}{*}{$\begin{array}{c}\text { Not } \\
\text { associated }\end{array}$} & & & \\
\hline & & & & Observed & Expected \\
\hline Ungrazed & 63 & 272 & 335 & 18.80 & 20.43 \\
\hline Grazed & 10 & 49 & 59 & 16.95 & 20.42 \\
\hline Overgrazed & 13 & 14 & 27 & 48.15 & 20.44 \\
\hline Total & 86 & 335 & 421 & & \\
\hline Chi-square test & & $\chi_{2}^{2}$ & 13.7 & $=0.001$ & \\
\hline
\end{tabular}

covered the pit wall with a fine nylon mesh before refilling with sieved soil. In the remaining 10 plants, we dug the pit and refilled it with sieved soil, but we did not cover the pit wall with a fine nylon mesh, allowing roots of the Stipa spp. plants access to the area. Ten seeds of B. pictus (palatable grass) were sown in each pit close to Stipa spp. tussocks. The seeds were harvested in the same study site in the previous growing season. The germination rate, measured in growth chambers, was $94 \pm 2.23 \%$ (mean \pm SE; Rotundo and Aguiar 2004). This experiment was repeated in the next growing season (May 2000) employing the same Stipa spp. tussocks selected during May 1999 but with a new randomization for competition treatments and removing old seedlings and seeds.

In both years, we counted and marked the emerged seedlings in October and followed surviving seedlings during the summer (January, dry season). For each surviving seedling, we measured height and number of leaves. We analyzed data as a 3-way analysis of variance (ANOVA) with a split-plot design: $2 \times 2 \times$ 2 (neighbor $\times$ competition $\times$ year). The main plot was year (1999-2000 or 2000-2001) and subplots were represented by neighbor ( $S$. speciosa or $S$. humilis) and competition (competition or reduced competition). We used the proper error term to test hypotheses about different sources of variation (Steel and Torrie 1988). Year and the replicates within each level of year were considered as random effects, whereas neighbor and competition were considered as fixed effects. Hence, we used a mixed model for the analyses. Emergence and survival data were angular transformed before analyses to fit a normal distribution. We performed multiple comparisons with least-significant difference tests and used the significance level of $5 \%$.

We calculated the intensity and relative importance of interspecific competition for each different year (Welden and Slauson 1986; Goldberg et al. 1999). The relative intensity was calculated as

$$
\text { intensity }=\frac{\left(X_{c o m p+}-X_{c o m p-}\right)}{X_{c o m p-}}
$$

where $X$ represents some mean of a response variable (emergence, survival, growth, or reproduction). This quotient indicates the severity of the ecophysiological stress induced 
Year 1999/00

a

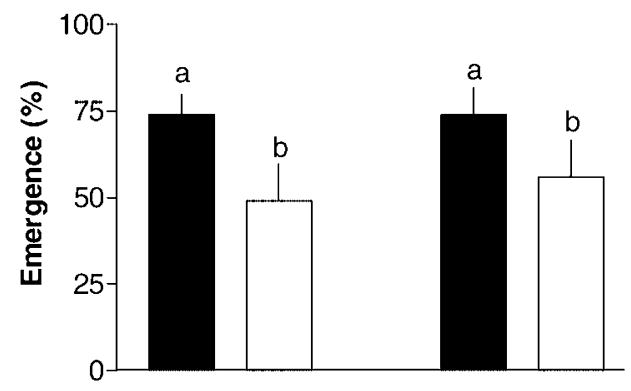

b

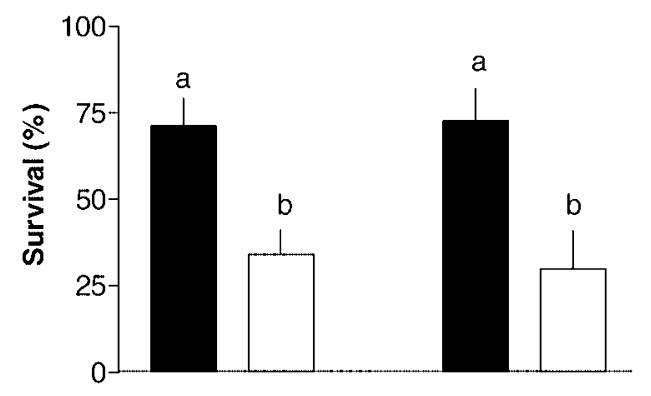

C

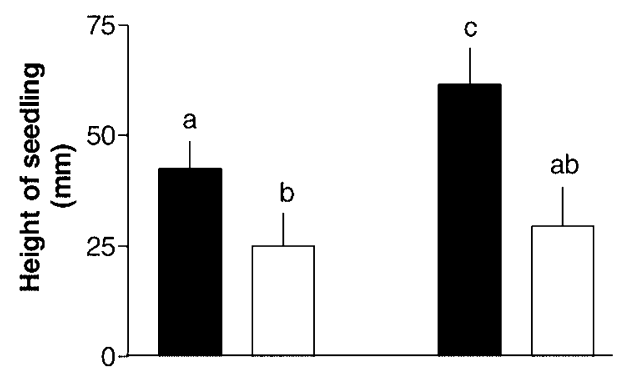

d
Year 2000/01
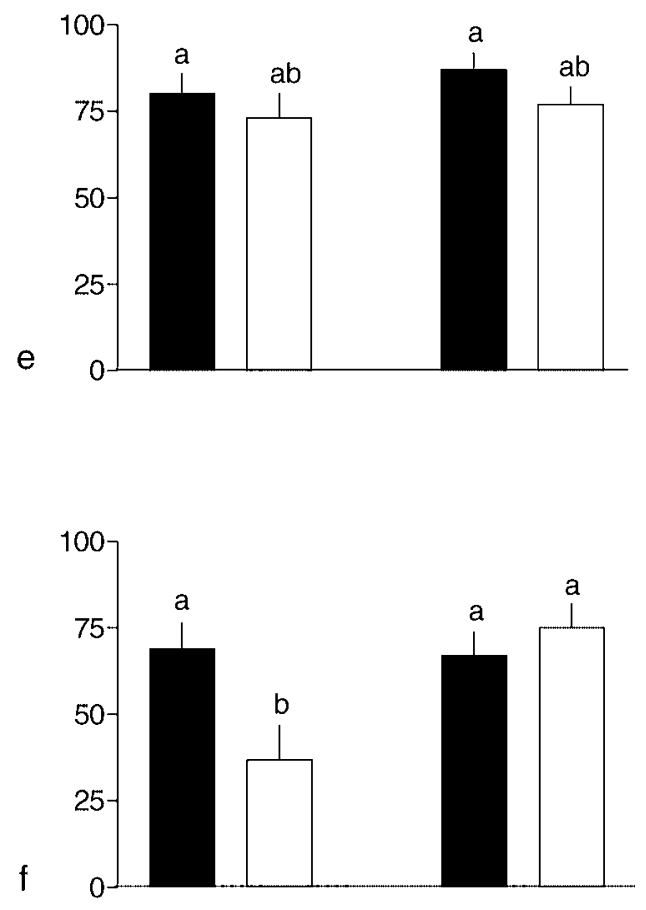

g

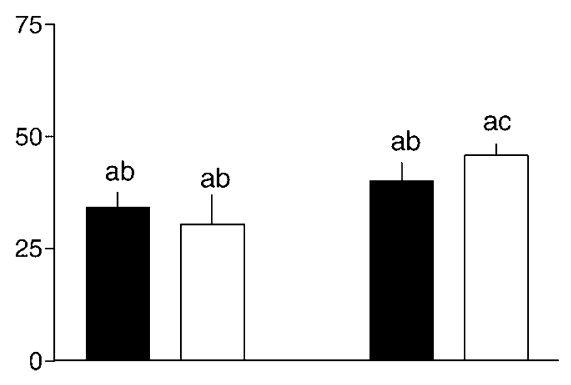

h

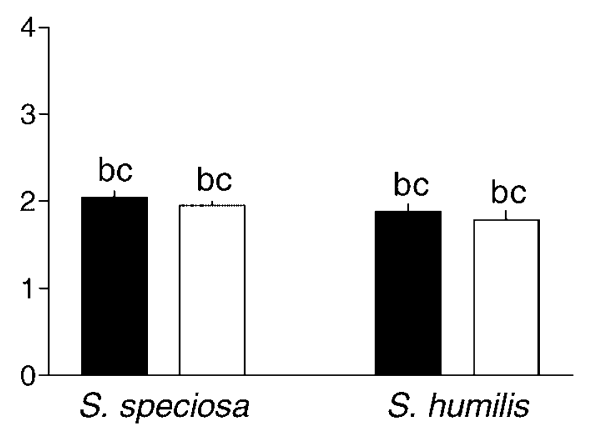

\section{Neighbor less palatable species}

Figure 2. a, e, Emergence. b, f, Survival. c, g, Height. d, h, Number of leaves of Bromus pictus seedlings for 2 different competition treatments and 2 different less palatable grass species as neighbor during 2 years (1999-2000 and 2000-2001). Emergence was calculated as the proportion of sown seed $(n=10)$ that emerged as seedlings. Survival was calculated as the proportion of emerged seedling that survived the dry season. Black bars indicate reduced competition and empty bars indicate full competition. Vertical bars indicate mean \pm SE. Different letters between bars indicate significant differences. 
Table 2. Summary of 3-way split-plot ANOVA (competition $\times$ neighbor $\times$ year) to 4 response variables (emergence, survival, height, and number of leaves for Bromus pictus seedlings). Competition levels are competition and reduced. Neighbor grass species levels are Stipa speciosa and Stipa humilis. Year levels are 1999-2000 and 2000-2001. Degrees of freedom (df), F-values and $P$-values are shown. Bold values indicate $P$-values $<5 \%$ and italic values indicate $P$-values $>5 \%$ and $<10 \%$.

\begin{tabular}{|c|c|c|c|c|c|c|c|c|}
\hline \multirow[b]{2}{*}{ Response variables } & & \multicolumn{7}{|c|}{ Source variation } \\
\hline & & Competition (C) & Neighbor (N) & Year $(Y)$ & $\mathrm{C} \times \mathrm{N}$ & $C \times Y$ & $\mathrm{~N} \times \mathrm{Y}$ & $\mathrm{C} \times \mathrm{N} \times \mathrm{Y}$ \\
\hline \multirow[t]{3}{*}{ Emergence } & $d f$ & 1,36 & 1,36 & 1,36 & 1,36 & 1,36 & 1,36 & 1,36 \\
\hline & $\mathrm{F}$ & 11.105 & 0.267 & 29.441 & 0.003 & 5.674 & 0.018 & 0.027 \\
\hline & $P$ & 0.001 & 0.606 & $<0.001$ & 0.958 & 0.019 & 0.895 & 0.870 \\
\hline \multirow[t]{3}{*}{ Survival } & $d f$ & 1,36 & 1,36 & 1,36 & 1,36 & 1,36 & 1,36 & 1,36 \\
\hline & $\mathrm{F}$ & 21.637 & 1.748 & 3.401 & 1.941 & 5.089 & 3.746 & 4.170 \\
\hline & $P$ & $<0.001$ & 0.191 & 0.069 & 0.168 & 0.027 & 0.057 & 0.045 \\
\hline \multirow[t]{3}{*}{ Height } & df & 1,36 & 1,36 & 1,36 & 1,36 & 1,36 & 1,36 & 1,36 \\
\hline & $\mathrm{F}$ & 7.183 & 6.459 & 0.207 & 0.088 & 8.576 & 0.015 & 1.830 \\
\hline & $P$ & 0.009 & 0.013 & 0.650 & 0.768 & 0.004 & 0.902 & 0.180 \\
\hline \multirow[t]{3}{*}{ Number of leaves } & $d f$ & 1,36 & 1,36 & 1,36 & 1,36 & 1,36 & 1,36 & 1,36 \\
\hline & $\mathrm{F}$ & 13.019 & 1.882 & 2.020 & 0.615 & 9.164 & 0.113 & 0.626 \\
\hline & $P$ & $<0.001$ & 0.174 & 0.159 & 0.436 & 0.003 & 0.737 & 0.431 \\
\hline
\end{tabular}

by full-competition $(\mathrm{comp}+)$ compared with the reducedcompetition situation (comp-). On the other hand, the relative importance of interspecific competition was calculated as

$$
\text { importance }=\frac{S S_{\text {competition }}}{S S_{\text {total }}}
$$

where $S S_{\text {competition }}$ is the square sum of competition factor and $S S_{\text {total }}$ is the total square sum from the ANOVA tables (Welden and Slauson 1986). The relative importance is the proportion of the total variation in the plant performance explained by the interspecific competition. Because our interest was to compare the changes in both competition indices across the years, we calculated them from $2 \times 2$ ANOVAs with neighbor and competition as the main fixed effects separately for each year.

\section{RESULTS AND DISCUSSION}

The proportion of $B$. pictus plants growing close to shrubs or less palatable tussock grasses increased in overgrazed conditions, and this increment was larger than the expected by chance (Table 1). This change in the spatial distribution pattern of B. pictus under higher grazing pressure can be the consequence of herbivore's behavior with respect to the preferred species and/or the effect of herbivores on refuge distribution in the field (Jeltsch et al. 1997; Beecham et al. 1999; Callaway et al. 2000; Rebollo et al. 2002; Oesterheld and Oyarzábal 2004). For example, in a semiarid shortgrass steppe, cactus clumps are avoided by herbivores and are natural refuges for sensitive species (Rebollo et al. 2002). Sites protected, hidden, or enclosed by shrub or woody thickets could limit easy access to medium or large herbivores. Similarly, growing close to less palatable species could obstruct the selective behavior of herbivores. The observation that the proportion of $B$. pictus individual plants that grow in association with less palatable species increases with grazing intensity confirm previous measurements (Oesterheld and Oyarzábal 2004) and supports a general pattern for the Patagonian steppe. It also raises questions about the implications for other population processes, such as seedling establishment, because other local processes, like interspecific competition, increase in importance (Soriano and Sala 1986; Owens and Norton 1992; Aguilera and Lauenroth 1993; Moretto and Distel 1997; Eccles et al. 2002).

The response of seedling performance to competition with less palatable grasses was different in the 2 years. During the 1999-2000 year, underground competition of neighbors reduced emergence, survival, and growth of B. pictus seedlings. In addition, there were no effects of neighbor species identity (S. speciosa or S. humilis). Competition reduced emergence by $30 \%$, survival by $55 \%$, height by $48 \%$, and number of leaves by $40 \%$ (Figs. 2a-d; Table 2). During the 2000-2001 year, underground competition with less palatable adult grasses did not reduce the emergence and growth of B. pictus seedlings (Figs. 2e, 2g, 2h; Table 2). In contrast, seedling survival was reduced by competition with $S$. speciosa (Fig. 2f; Table 2). Also, the height of $B$. pictus seedlings differed according to neighbor's species, independently of competition and year. Seedlings growing close to $S$. speciosa were shorter than those growing close to $S$. humilis (Fig. 2g; Table 2).

The intensity and relative importance of underground competition on $B$. pictus seedlings varied with the year considered (Fig. 3; Table 2). Our results showed high intensity and relative importance of interspecific competition during the first year (1999-2000). The accumulated rainfall during the first year was lower than the site average (101.9 mm vs. $118.5 \mathrm{~mm}$ ) (Fig. 1). However, during the second year (2000-2001), the accumulated rainfall was larger than the site average $(135.8 \mathrm{~mm}$ vs. $118.5 \mathrm{~mm}$ ) and was concentrated toward the end of spring (Fig. 1), a key period to define the seedling recruitment in the Patagonian arid steppe because it determines the size of the root at the start of the drought period in December (Aguiar et al. 1992).

Competition is a common biotic interaction in arid ecosystems (Fowler 1986; Goldberg and Barton 1992; Aguilera and Lauenroth 1993), but its intensity varies in space and time. Because competition occurs between neighbors, the frequency 

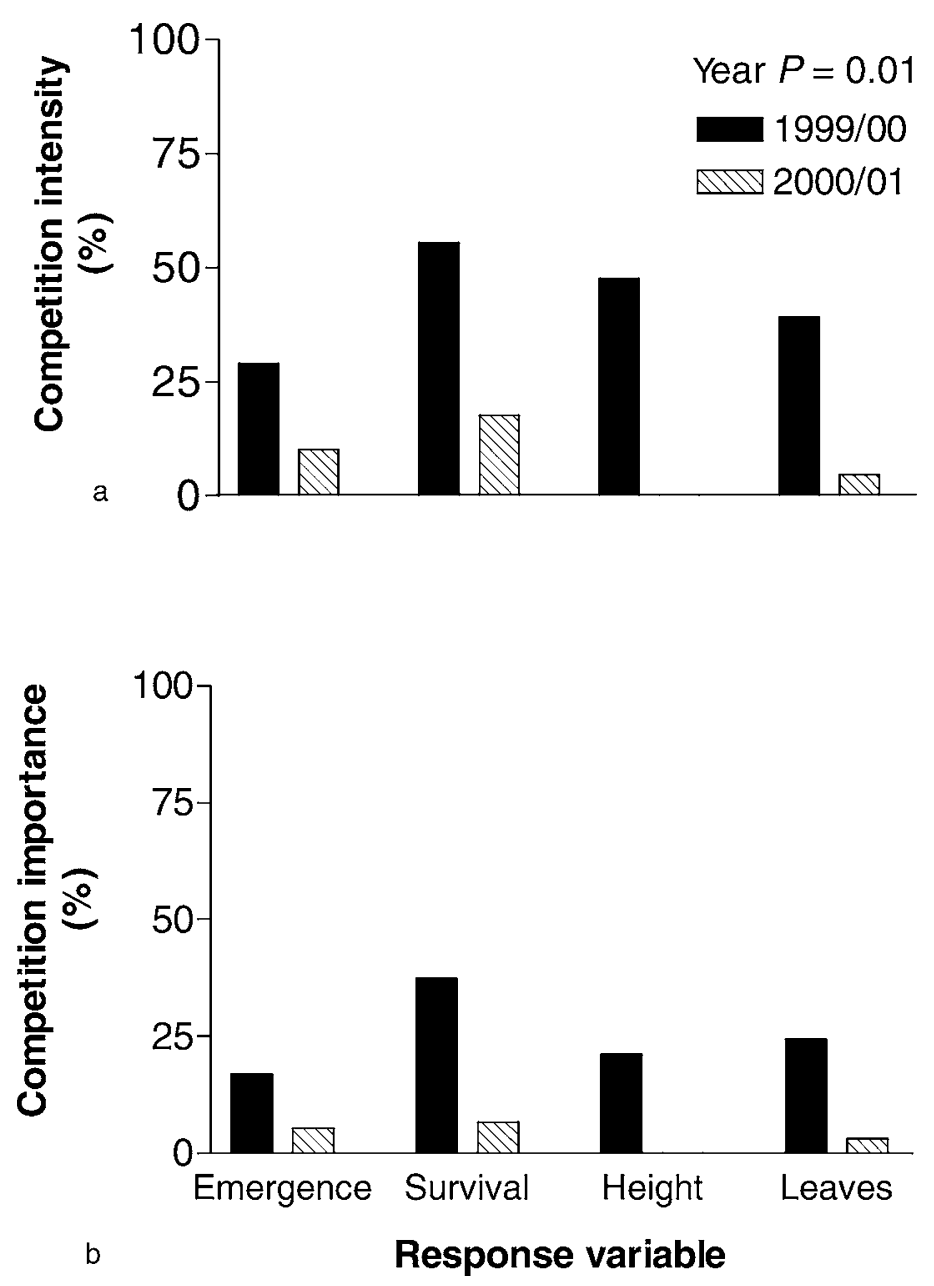

Figure 3. a, Intensity. b, Relative importance of interspecific competition between Bromus pictus and less palatable grasses (Stipa spp.) across 4 response variables: emergence, survival, height, and number of leaves during 2 years (1999-2000 and 2000-2001).

of interspecific encounters or interactions is determined by plant spatial pattern. Our plant-pattern study indicated that, as grazing intensity increases, the frequency of interspecific interaction increases independently of the relative density of the species (i.e., palatable or less palatable). On the other hand, temporal variation is also important because our data indicate differences according to the year, probably related to water availability. This is an important issue for arid and semiarid ecosystems, such as the Patagonia steppe, because the interannual variability (measured as the coefficient of variation) increases as mean annual precipitation decreases (Oesterheld et al. 1999). To our knowledge, few studies deal with the space and time variability of plant competition between grass species that we addressed in our study (cf. Goldberg and Barton 1992; but see Tielbörger and Kadmon 2000).

\section{MANAGEMENT IMPLICATIONS}

Plant density of palatable species is a common way to infer the condition and functioning of rangelands. Recently, it has been proposed that plant distribution in relation to grazing regime is another important aspect to consider (Adler et al. 2001; Cipriotti and Aguiar 2005). Density and spatial plant distribution control many population processes relevant to rangeland management (establishment, growth, or reproduction). We found evidence that, potentially, there is an adult-seedling conflict because less palatable neighbors can increase adult survival chances but may constrain seedling performance of palatable species. This conflict may increase in normal to dry years and interact according to the dominant less palatable grass species. These are important issues for designing restoration practices in degraded rangelands because 1) the climatic variation offers windows of opportunity for overcoming the constraint to recruitment of new individuals by sexual reproduction; 2) the dominant less palatable species influences the recovery probability and interacts in different ways with climatic conditions; and 3) in rangelands, like the Patagonian steppe, where wind moves seed toward established vegetation (Aguiar and Sala 1997), restoration success can be hampered by plant-seedling competition. It is important to overcome this by promoting burial of seeds in bare grounds. Grazing at seed dispersal time is a tool to achieve this goal (Rotundo and Aguiar 2004).

\section{ACKNOWLEDGMENTS}

We thank Pablo Roset for his help during the field work. INTA kindly granted the access to the Rio Mayo Experimental Field and facilities. We also thank Vanina Cipriotti for her help with the English writing and Martín Oesterheld for thoughtful comments on an advance version of the manuscript. The studies and experiments in this manuscript comply with the ethics guidelines and current laws of Argentina.

\section{LITERATURE CITED}

Adler, P. B., D. A. Raff, and W. K. Lauenroth. 2001. The effect of grazing on the spatial heterogeneity of vegetation. Oecologia 128:465-479.

Aguiar, M. R., P. A. Cipriotti, W. B. Batista, and A. C. Premoli. 1999. Viabilidad de poblaciones de gramíneas patagónicas en peligro de extinción por sobrepastoreo. Libro de resúmenes de la IXX Reunión Argentina de Ecologí. Tucumán, Argentina.

AgUiar, M. R., AND O. E. Sala. 1997. Seed distribution constrains the dynamics of the Patagonian steppe. Ecology 78:93-100.

Aguiar, M. R., A. Soriano, and O. E. Sala. 1992. Competition and facilitation in the recruitment of seedlings in the Patagonian steppe. Functional Ecology 6:66-70.

Aguilera, M. O., and W. K. Lauenroth. 1993. Seedling establishment in adult neighbourhoods: intraspecific constraints in the regeneration of the bunchgrass Bouteloua gracilis. Journal of Ecology 81:253-261.

ARCHER, S. 1989. Have southern Texas savannas been converted to woodlands in recent history? American Naturalist 134:545-561.

ARCHER, S. 1990. Development and stability of grass/woody mosaics in a subtropical savanna parkland, Texas, U.S.A. Journal of Biogeography 17:453-462.

BAKKER, J. P., J. DE LeEUw, AND S. E. van WieREN. 1983. Micropatterns in grassland vegetation created and sustained by sheep-grazing. Vegetatio 55:153-161.

Beecham, J. A., S. P. Oom, and A. J. Hester. 1999. The role of animal decisions in the development of vegetation mosaics. Heterogeneity in landscape ecology: pattern and scale. Proceedings of the 8th Annual Conference of the International Association for Landscape Ecology; 6-8 September 1999; Bristol, UK. p 121-130.

BELSKY, J. A. 1992. Effects of grazing, competition, disturbance and fire on species 
composition and diversity in grassland communities. Journal of Vegetation Science 3:187-200.

Berg, G., P. Esselink, M. Groenewg, and K. Kieht. 1997. Micropatterns in Festuca rubra dominated vegetation induced by sheep grazing. Plant Ecology 132:1-14.

Bonvissuto, G., O. Moricz de Tecso, O. Astibia, and J. Anchorena. 1983. Resultados preliminares sobre los hábitos dietarios de ovinos en un pastizal semidesértico de Patagonia. Boletín Informativo de Investigación Agropecuaria (INTA) 36:243-253.

Brown, R. J., AND S. ARCheR. 1989. Woody plant invasion of grasslands: establishment of honey mesquite (Prosopis glandulosa) on sites differing in herbaceous biomass and grazing history. Oecologia 80:19-26.

Callaway, R. M., Z. KiKVIDZE, AND D. KiKodZE. 2000. Facilitation by unpalatable weeds may conserve plant diversity in overgrazed meadows in the Caucasus Mountains. Oikos 89:275-282.

Cipriotti, P. A., And M. R. Aguiar. 2005. Effects of grazing on patch structure in a semi-arid two-phase vegetation mosaic. Journal of Vegetation Science 16: $57-66$.

Crawley, M. J. 1990. Rabbit grazing, competition and seedling recruitment in acid grassland. Journal of Applied Ecology 27:803-820.

Dale, M. R. T., and M. W. Zbigniewicz. 1997. Spatial pattern in boreal shrub communities: effects of a peak in herbivore density. Canadian Journal of Botany 75:1342-1348.

Defosse, G. E., R. Robberecht, and M. B. Bertiller. 1997. Seedling dynamics of Festuca spp. in a grassland of Patagonia, Argentina, as affected by competition, microsites and grazing. Journal of Range Management 50:73-79.

Eccles, N., B. Lamont, K. Esler, and H. Lamont. 2002. Relative performance of clumped vs. experimentally isolated plants in a South African winter-rainfall desert community. Plant Ecology 159:117-117.

Fernández Aldúncin, R. J., O. E. Sala, and R. A. Golluscio. 1991. Woody and herbaceous aboveground production of a Patagonian steppe. Journal of Range Management 44:434-437.

FowLER, N. L. 1986. The role of competition in plant communities in arid and semiarid regions. Annual Review in Ecology and Systematics 17:89-110.

FowLER, N. L. 2002. The joint effects of grazing, competition, and topographic position on six savanna grasses. Ecology 83:2477-2488.

Goldberg, D. E., And A. M. Barton. 1992. Patterns and consequences of interspecific competition in natural communities: field experiments with plants. American Naturalist 139:771-801.

Goldberg, D. E., T. Rajaniemi, J. Gurevitch, and A. Stewart-Oaten. 1999. Empirical approaches to quantifying interaction intensity: competition and facilitation along productivity gradients. Ecology 80:1118-1131.

Golluscio, R. A., R. J. C. León, and S. B. Perelman. 1982. Caracterización fitosociológica de la estepa del oeste de Chubut, su relación con el gradiente ambiental. Boletín de la Sociedad Argentina de Botánica 21:299-324.

Golluscio, R. A., ANd 0. E. SalA. 1993. Plant functional types and ecological strategies in Patagonian forbs. Journal of Vegetation Science 4:839846.

Jeltsch F., S. J. Milton, W. R. J. Dean, N. van Rooyen, and M. W. Harcombe. 1997. Simulated pattern formation around artificial waterholes in the semi-arid Kalahari. Journal of Vegetation Science 8:177-188.

Jobbágy, E. G., J. M. Paruelo, and R. J. C. León. 1995. Estimación del régimen de precipitatción a partir de la distancia a la cordillera en el noroeste de la Patagonia. Ecología Austral 5:47-53.

JobBágy, E. G., AND O. E. SALA. 2000. Controls of grass and shrubs aboveground production in the Patagonian steppe. Ecological Applications 10:541-549.

León, R. J. C, D. Bran, M. Collantes, J. M. Paruelo, and A. Soriano. 1998. Grandes unidades de vegetación de la Patagonia extra andina. Ecología Austral 8:125-144.

McNaughton, S. J. 1993. Biodiversity and function of grazing ecosystems. In:
Shulze and H. A. Mooney [eds.]. Biodiversity and ecosystem function. Berlin, Germany: Springer-Verlag. p 361-383.

Milchunas, D. G., W. K. Lauenroth, P. L. Chapman, and M. K. Kazempour. 1989. Effects of grazing, topography, and precipitation on the structure of a semiarid grassland. Vegetatio 80:11-24.

Moretto, A. S., AND R. A. Distel. 1997. Competitive interactions between palatable and unpalatable grasses native to a temperate semi-arid grassland of Argentina. Plant Ecology 130:155-161.

Oesterheld, M., J. Loreti, M. Semmartin, and J. M. Paruelo. 1999. Grazing, fire, and climate effects on primary productivity of grasslands and savannas. In: Walker [ed.]. Ecosystems of disturbed ground. Amsterdam: Elsevier. p 287-306.

Oesterheld, M., and M. Oyarzábal. 2004. Grass-to-grass protection from grazing in a semi-arid steppe. Facilitation, competition, and mass effect. Oikos 107:576-582.

OWEns, M. K., AND B. E. NoRton. 1992. Interactions of grazing and plant protection on basin big sagebrush (Artemisia tridentata ssp. tridentata) seedling survival. Journal of Range Management 45:257-262.

Papatheodorou, E., J. D. Pantis, and G. P. Stamou. 1993. The effects of grazing on growth, spatial pattern and age structure of Quercus coccifera. Acta Oecologica 14:589-602.

Paruelo, J. M., M. R. Aguiar, and R. A. Golluscio. 1988. Soil water availability in the Patagonian arid steppe: gravel content effect. Arid Soil Research Rehabilitation 2:67-74.

Perelman, S. B., R. J. C. León, and J. P. Bussacca. 1997. Floristic changes related to grazing intensity in a Patagonian shrub steppe. Ecography 20:400-406.

Rebollo, S., D. G. Milchunas, I. Noy-Meir, and P. L. Chapman. 2002. The role of a spiny plant refuge in structuring grazed shortgrass steppe plant communities. Oikos 98:53-64.

Rotundo, J. L., AND M. R. Aguiar. 2004. Vertical seed distribution in soil constrains regeneration processes of Bromus pictus in a Patagonian steppe. Journal of Vegetation Science 15:514-522.

Schlesinger, W. H., J. F. Reynolds, G. L. Cunningham, L. F. Huenneke, W. M. JarRell, V. A. Ross, and W. G. Whitford. 1990. Biological feedbacks in global desertification. Science 247:1043-1047.

Somlo R., A. Pelliza, P. Willems, V. Nakamatsu, and A Manero. 1997. Atlas dietario de herbívoros patagónicos. Chubut, Prodesar GTZ-INTA, FA0. p 109.

Soriano, A. 1956. Los distritos florísticos de la provincia Patagónica. Revista de Investigación Agropecuaria 10(4):323-347.

Soriano, A., C. P. Movia, And R. J. C. León. 1983. Deserts and semideserts of Patagonia. In: N. E. West [ed.]. Temperate deserts and semideserts. Amsterdam: Elsevier Scientific Publishing Company. p 423-457.

Soriano, A., AND O. E. SalA. 1986. Emergence and survival of Bromus setifolius seedlings in different microsites of a Patagonian arid steppe. Israel Journal of Botany 35:91-100.

Steel, R. G. D., and J. M. Torrie. 1988. Principles and procedures of statistics. New York, NY: McGraw-Hill. p 622.

TielbÖRGER, K., AND R. KadmON. 2000. Temporal environmental variation tips the balance between facilitation and interference in desert plants. Ecology 81: 1544-1553.

VAN AUKEN, 0. W. 2000. Shrub invasions of North American semiarid grasslands. Annual Review of Ecology and Systematics 31:197-215.

Walker, B. H., D. Ludwig, C. S. Holling, and R. M. Peterman. 1981. Stability of semiarid savanna grazing systems. Journal of Ecology 69:473-498.

Welden, C. W., and W. L. Slauson. 1986. The intensity of competition versus its importance: an overlooked distinction and some implications. The Quarterly Review of Biology 61:23-44.

Westoby, M. 1980. Elements of a theory of vegetation dynamics in arid rangelands. Israel Journal of Botany 28:169-194. 